\title{
IMPACTS OF PUSHING AND PULL FACTORS ON TOURIST SATISFACTION AND RETURN INTENTION TOWARDS RIVER TOURISM IN CAN THO CITY, VIETNAM
}

\author{
Quoc Nghi NGUYEN* \\ Can Tho University, School of Economics, Can Tho City, Vietnam, e-mail: quocnghi@ctu.edu.vn \\ Van Nam MAI \\ Can Tho University, School of Graduate, Can Tho City, Vietnam, e-mail: mvnam@ctu.edu.vn
}

\begin{abstract}
Citation: Nguyen, Q.N. \& Mai, V.N. (2021). IMPACTS OF PUSHING AND PULL FACTORS ON TOURIST SATISFACTION AND RETURN INTENTION TOWARDS RIVER TOURISM IN CAN THO CITY, VIETNAM. GeoJournal of Tourism and Geosites, 38(4), 1011-1016. https://doi.org/10.30892/gtg.38404-738
\end{abstract}

\begin{abstract}
This study was conducted to demonstrate the impacts of push and pull factors on tourist satisfaction and behavioural intention of visitors towards Can Tho City river tourism. Structural Equation Modeling (SEM) was used to analyse the data. Research data were collected by direct interviews with 235 visitors who have experienced the river tour in Can Tho City. The research has shown that push and pulls factors positively affect destination satisfaction. Besides, destination satisfaction promotes the return intention, willingness to pay, and positive word of mouth of visitors towards river tourism. The study proposes important implications to effectively use river tourism image of Can Tho City, thereby attracting both domestic and foreign tourists. These solutions may help improve the tourism industry of the city.
\end{abstract}

Key words: Push factors, pull factors, destination satisfaction, behavioural intention, river tourism

\section{INTRODUCTION}

Tourism is the "smokeless industry" with the most reliable and most sustainable growth rate in the world (Bansal and Eiselt, 2004). Along with the rapid development of the tourism industry, the competition among tourist destinations, especially the river destinations, has become increasingly cruel. To achieve the success which marketing strategies need to be considered based on analyzing the relationships among tourism motivation, destination satisfaction, and behavioural intention of visitors (Yoon and Uysal, 2005). According to Cooper and Prideaux (2009), river tourism is a form of waterway tourism that is exploited and organized based on natural freshwater flows (rivers, canals, etc.). Its attraction comes not only from the natural scenery but also from the culture. It includes activities such as yachting, sightseeing, entertainment, leisure, events taken place on both sides of the rivers.

Can Tho City locates on the banks of Hau Giang River, and it is the central city of the Mekong Delta region. This city has potential resources for tourism development, especially river tourism, as Cai Rang and Phong Dien floating market (in Cai Rang District and Phong Dien District). Son Island (in Binh Thuy District) and Tan Loc Islands (in Thot Not District) are famous places to international travellers. They are destinations for both domestic and foreign tourists and interlace river systems together with luxuriant fruit gardens with beautiful landscapes. Besides, the local culture in "Tay Do" land (another name of Can Tho City) associated with the river has attracted many international tourists so far. However, development strategies on river tourism are still not commensurate with the potentials and advantages of the city. To utilize this advantage, push and pull factors need to be taken into consideration to create attractive tourist products, improve satisfaction and positive behavioural intention of tourists towards river tourism.

\section{THEORETICAL FRAMEWORK AND RESEARCH HYPOTHESES}

\section{Theoretical framework}

\section{Push factor}

Push factors are motivational factors, resulting from imbalance or pressure in the motivation system. Analyzing tourism motivation is exciting and essential to researchers in the world including different areas of research such as sociological research, anthropology, and psychology (Dann, 1977; Crompton, 1979; Gnoth, 1997). Researchers have shown that motivation was the deciding factor that affects travel behaviour. Motivation is considered as personal orientation enticing an individual to travel conduct. The behaviour may include visiting for the reasons for escaping from the daily routine, spending time with family or adventure needs (Dann, 1977; Chon, 1989).

\section{Pull factor}

The concept of pull factor is defined related to features, attractions or properties of destinations, such as "floating market", "water resource", "beautiful landscape" or "historical and cultural resources" (Fakeye and Crompton, 1991; Hu and Ritchie,

\footnotetext{
* Corresponding author
} 
1993; Kim et al., 2003). Destination choices come from tourists' reviews about destination properties (Kim et al., 2003). Pull factors are tangible resources, perception, and expectations of tourists about the features, attractions or parks of a particular destination. Therefore, pull factors play an essential role in tourist destination choice (Crompton, 1979; Kim et al., 2003).

\section{Destination satisfaction}

Severt et al. (2007) pointed out that tourist satisfaction is expressed through the experiences of a product or service that meets their expectations regarding the trip. Satisfaction is created by comparing what visitors expect to receive and what they received (Kim et al., 2003). Visitors are satisfied when the experience goes far beyond expectations (Chen and Chen, 2009; Reisinger and Turner, 2012). Working on visitor satisfaction is a crucial issue to reach the success in target marketing because it affects the destination choice, product and service consumption as well as return intention (Kozak and Rimmington, 2000).

\section{Behavioural intention}

The behavioural intention has been conceptualized and measured according to different criteria. Zeithaml et al. (1996) pointed out five types of customer behavioural intention after experiencing the service, namely: loyalty, willingness to pay, switching purpose, internal, and external feedback. According to Richard (2014), behavioural intention is expressed in the short and long term. In Chen and Tsai's study (2007), tourist behavioural intention is shown by the intention to return to the destination and the willingness to recommend the goal to others. Word of mouth, complaint or compliment, and suggestion are considered short-term behaviour, while loyalty is regarded as long-term behaviour (Chan et al., 2015).

\section{Research hypotheses}

\section{Push factors affect tourist satisfaction}

In a study in 2008, Qiao et al. confirmed that push factors affect the return intention of visitors directly and indirectly through destination satisfaction. Ryan and Deci (2000) have shown that activities with positive motivation will stimulate individual awareness about achievement. The positive relationship between push factors and tourist satisfaction was also found in the research by Zupan and Milfelner (2014). In addition to this, intrinsic motivations or psychological factors positively affect tourist satisfaction as well as their behavioural intention in the future (Fangxuan and Chris, 2015; Pratminingsih et al. (2013). Therefore, the hypothesis H1 is proposed as follow: H1: Push factors positively affect destination satisfaction towards river tourism in Can Tho City.

\section{Pull factors impacts tourist satisfaction}

Pull factors are considered as external properties of a destination, significantly affect tourist satisfaction and intention to return (Qiao et al., 2008). Researches by Fangxuan and Chris (2015), Pratminingsih et al. (2013) have demonstrated that the external motives of the destination attribute positively affect tourist satisfaction. In other words, the pleasure and intention to return to a tourist site depend mainly on the level of visitors' awareness about the destination image, instead of their desires and needs (Mai and Huynh, 2014). As a result, the study proposes hypothesis H2 as follow: H2: Pull factors positively affect destination satisfaction towards river tourism in Can Tho City.

\section{Destination satisfaction impacts the return intention}

Several studies have pointed out the positive relationship between tourist satisfaction and the plan to return to a destination (Ross and Iso-Ahola, 1991; Pizam, 1994; Hallowell, 1996; Beeho and Prentice, 1997). Visitors are willing to seek alternative destinations for further trips and have harmful word-of-mouth intentions if they are not satisfied with the current goal (Peter and Olson, 1987; Pizam, 1994). Furthermore, satisfaction is considered to be an essential factor affecting visitor behavioural intention (Yoon and Uysal, 2005; Pratminingsih et al., 2013; Hasan et al., 2020; Hossain et al., 2021). This has shown that the more tourists are satisfied with the destination, the higher the intention to return. Base on the above discussion, the hypothesis H3 is stated as follows:

\section{H3: Destination satisfaction positively affects the return intention towards river tourism in Can Tho City.}

\section{Destination satisfaction affects the willingness to pay}

There have been studies showing the relationship between service satisfaction and the willingness to pay. Zeithaml et al. (1993) argued that if tourists experience high-quality services in the trip, they will be willing to pay more. In another research, Homburg et al. (2005) pointed out that the increase in customer satisfaction leads to the willingness to pay for the service. Tourists' willingness to pay is positively correlated with their destination satisfaction. This means visitors are willing to pay more for services that bring higher comfort (Latiff and Imm, 2013). Hence, the study puts forward the hypothesis H4 as follow:

\section{H4: Destination satisfaction positively affects tourists' willingness to pay towards river tourism in Can Tho City.}

\section{Satisfaction with the destination effects word-of-mouth intention}

According to Rust et al. (1995), when visitors are satisfied with the destination, they tend to have a positive word of mouth about the destination for relatives and friends. Similarly, Latiff and Imm (2013) showed a dynamic relationship between satisfaction on the service quality and positive word-of-mouth intention. Ivyanno (2013) suggested that if tourists are satisfied with the activities and the service quality of the tourist site, they tend to recommend it to their friends and relatives. Thereby, satisfaction has a positive impact on word-of-mouth intention, which is an essential factor to attract tourists (Carvache-Franco et al., 2020; Hossain et al., 2021). Therefore, the following hypothesis is stated: 
H5: Destination satisfaction positively affects the word-of-mouth intention of tourists towards river tourism in Can Tho City.

Based on the literature review mentioned above, the research model about the impacts of push and pull factors on tourist satisfaction and return intention towards river tourism in Can Tho City was proposed as follows:

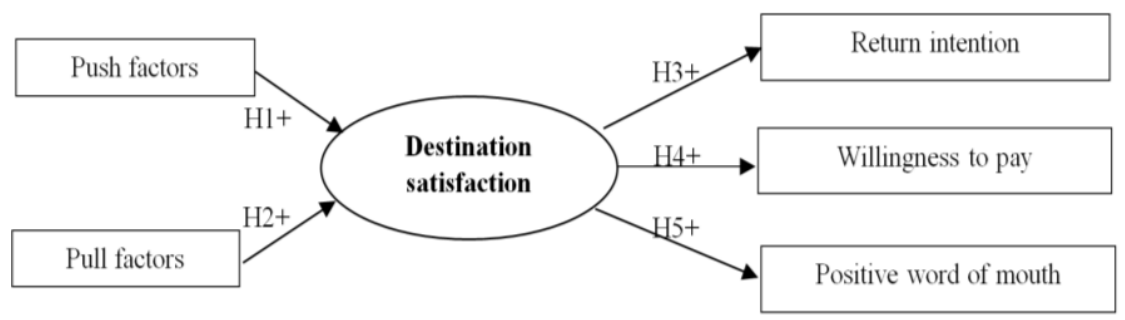

Figure 1. Proposed research model

Table 1. Interpretation of observed variables in the research model

\begin{tabular}{|c|c|c|c|}
\hline Factors & Observed variables & Scale & Reference sources \\
\hline \multirow{6}{*}{$\begin{array}{c}\text { Push } \\
\text { factors }\end{array}$} & PUS1: Look forward to learning new things. & Likert 1-5 & \multirow{6}{*}{$\begin{array}{l}\text { Qiao et al. (2008), } \\
\text { Ryan and Deci } \\
\text { (2000), Zupan and } \\
\text { Milfelner (2014), } \\
\text { Pratminingsih et al. } \\
(2013)\end{array}$} \\
\hline & PUS2: Enjoy meeting new friends. & Likert 1-5 & \\
\hline & PUS3: Enjoy experiencing the beauty of the natural river system. & Likert 1-5 & \\
\hline & PUS4: Enjoy exploring the culture and history of the river systems. & Likert 1-5 & \\
\hline & PUS5: Love to experience the lifestyle on the river. & Likert 1-5 & \\
\hline & PUS6: Love to relax by the river. & Likert 1-5 & \\
\hline \multirow{6}{*}{$\begin{array}{l}\text { Pull } \\
\text { factors }\end{array}$} & PUL1: The natural beauty of the river is attractive. & Likert 1-5 & \multirow{6}{*}{$\begin{array}{l}\text { Qiao et al. (2008), } \\
\text { Fangxuan and Chris } \\
\text { (2015), } \\
\text { Pratminingsih et al. } \\
\text { (2013) }\end{array}$} \\
\hline & PUL2: The Culture and history of the river are exciting. & Likert $1-5$ & \\
\hline & PUL3: Dishes are typical, delicious, and unique. & Likert 1-5 & \\
\hline & PUL4: Can Tho people are friendly and hospitable. & Likert $1-5$ & \\
\hline & PUL5: Transportation and rest areas are convenient. & Likert 1-5 & \\
\hline & PUL6: Fluvial products are novel and attractive. & Likert 1-5 & \\
\hline \multirow{5}{*}{$\begin{array}{l}\text { Destination } \\
\text { satisfaction }\end{array}$} & DS1: Choosing the river destination in Can Tho City is a worthy decision. & Likert 1-5 & \multirow{5}{*}{$\begin{array}{l}\text { Severt et al. (2007), } \\
\text { Kim et al. (2003), } \\
\text { Chen and Chen } \\
\text { (2010), Reisinger and } \\
\text { Turner (2012), Kozak } \\
\text { and Rimmington, } \\
(2000)\end{array}$} \\
\hline & DS2: Satisfied with the culture and history of the river systems in Can Tho City. & Likert 1-5 & \\
\hline & DS3: Satisfied with the fluvial products and cuisine in Can Tho City. & Likert 1-5 & \\
\hline & DS4: Satisfied with the natural landscape and the river environment in Can Tho City. & Likert 1-5 & \\
\hline & DS5: The trip and experiences meet my expectations. & Likert $1-5$ & \\
\hline \multirow{4}{*}{$\begin{array}{l}\text { Return } \\
\text { intention }\end{array}$} & $\begin{array}{l}\text { RI1: I will use more products and services of the river tour in Can Tho City in the } \\
\text { future. }\end{array}$ & Likert $1-5$ & \multirow{4}{*}{\begin{tabular}{|l|} 
Pizam (1994), \\
Hallowell (1996), \\
Beeho and Prentice \\
(1997), Peter and \\
Olson (1987), Yoon \\
and Uysal, (2005) \\
\end{tabular}} \\
\hline & RI2: River tour in Can Tho City will be my prior choice. & Likert 1-5 & \\
\hline & RI3: I will keep in touch with the people I knew at Can Tho River tourist sites. & Likert 1-5 & \\
\hline & RI4: I will return to Can Tho City to experience a river tour soon. & Likert $1-5$ & \\
\hline \multirow{4}{*}{$\begin{array}{c}\text { Willingness } \\
\text { to pay }\end{array}$} & WTP1: If the travel cost increases, I am still willing to experience river tourism in Can Tho City. & Likert 1-5 & \multirow{4}{*}{$\begin{array}{l}\text { Homburg et al. } \\
(2005), \text { Latiff and } \\
\text { Imm (2013) }\end{array}$} \\
\hline & WTP 2: I am willing to pay more than planned to experience Can Tho River tour. & Likert 1-5 & \\
\hline & WTP 3: The cost of the trip deserves what I got. & Likert 1-5 & \\
\hline & WTP 4: I am willing to pay to experience Can Tho River tour again. & Likert 1-5 & \\
\hline \multirow{4}{*}{$\begin{array}{l}\text { Word of } \\
\text { mouth }\end{array}$} & WOM1: I will share the information about Can Tho River tourist sites with my community. & Likert 1-5 & \multirow{4}{*}{$\begin{array}{l}\text { Rust et al. (1995), } \\
\text { Latiff and Imm } \\
\text { (2013), Ivyanno } \\
\text { (2013) }\end{array}$} \\
\hline & WOM 2: I will recommend Can Tho River tour to my relatives and friends. & Likert 1-5 & \\
\hline & WOM 3: I will give good reviews for Can Tho River tour. & Likert 1-5 & \\
\hline & WOM 4: I will suggest my relatives and friends take Can Tho River tour as a prior choice. & Likert 1-5 & \\
\hline
\end{tabular}

\section{RESEARCH METHODOLOGY}

\section{Analytical method}

In this study, the quantitative analysis is used in the following order: Step 1: Test the reliability of the scales by Cronbach's Alpha. Step 2: Exploratory factor analysis (EFA) to evaluate the convergent and discriminant validity. Step 3: Confirmatory factor analysis (CFA) to assess the relevance of the data to the market. Step 4: Structural equation modeling (SEM) to test the proposed research hypotheses.

\section{Data collection method}

The SEM method requires a large sample size because it relies on the pattern distribution theory (Raykov and Widaman, 1995). The sample size has to be between 100 and 200 (Hoyle, 1995). According to Hoelter (1983), to ensure the reliability of the SEM method, the limited sample size in SEM is 200. In this study, the quota sampling method and direct interview were used to collect data. Subjects of the study are tourists who have visited and experienced Can Tho River tour. The number of surveyed visitors is 250 . After eliminating 15 forms that are not sufficiently adequate, the study reached the final sample size of 235 observations, of which 71 international visitors accounted for 30.21\%. During the survey process, demographic factors were focused on the representativeness of the research data. 


\section{RESEARCH RESULTS AND DISCUSSIONS}

\section{Scale reliability test}

Cronbach's alpha coefficient was used to assess the reliability of the scales. Based on the test results in Table 1, 6 factors with 29 observed variables have high-reliability coefficients (above 0.79), and all these variables have Corrected item-total Correlation greater than 0.3. This proves all the observed variables and scales ensure reliability (Nunnally, 1978; Peterson, 1994). Therefore, six factors and 29 observed variables can be used for the next Exploratory Factor Analysis (EFA).

\section{Exploratory factor analysis (EFA)}

EFA analysis was used to determine the convergent validity and discriminant validity of the scales. In this research, EFA analysis was used three times. The first EFA result with Push and Pull factors scales achieved the following values: (1) Reliability of variables (Factor loading $>0.5)$; (2) Research model's suitability test $(0.5<\mathrm{KMO}=0.930<1.0)$; $(3)$ Bartlett's test for correlation of variables (Sig. $=0.00<0.05$ ); (4) Cumulative variance test $=60.652 \%>50 \%$. This proves that all observed variables achieved convergent validity and discriminant validity (Hair et al., 1998).

Thereby, two factors were formed from 12 observed variables. There was no disturbance among factors, so the factors' names were retained. Similarly, the second EFA result with the destination satisfaction scale achieved the following indicators: (1) Reliability of variables (Factor loading $>0.5)$; (2) Research model's suitability test $(0.5<$ $\mathrm{KMO}=0.889<1.0$ ); (3) Bartlett's test for correlation of variables (Sig. $=0.00<0.05$ ); (4) Cumulative variance test $=$ $59.917 \%>50 \%$. Thereby, observed variables achieved convergent validity and discriminant validity (Hair et al., 1998). Hence, the Destination satisfaction scale has five observed variables as the proposed model. Finally, the third EFA result with the Return intention, Willingness to pay, and Word of mouth scales achieved the following values: (1) Reliability of variables (Factor loading > 0.5); (2) Research model's suitability test $(0.5<\mathrm{KMO}=0.903<1.0)$; (3) Bartlett's test for correlation of variables (Sig. $=0.00<0.05$ ); (4) Cumulative variance test $=67.281 \%>50 \%$. Therefore, observed variables achieved convergent validity and discriminant validity (Hair et al., 1998). As a result, three factors were formed from 12 observed variables; there was no disturbance of factors, so the factors' names were still the same.

Table 2. Result of Cronbach's Alpha analysis (Source: Survey data, 2020)

\begin{tabular}{|l|c|c|c|}
\hline \multicolumn{1}{|c|}{ Scale } & $\begin{array}{c}\text { Cronbach's } \\
\text { Alpha }\end{array}$ & $\begin{array}{c}\text { Corrected Item- } \\
\text { Total Correlation }\end{array}$ & $\begin{array}{c}\text { Max Cronbach's } \\
\text { Alpha if item } \\
\text { deleted }\end{array}$ \\
\hline Push factors & 0.885 & 0.635 & 0.875 \\
\hline Pull factors & 0.839 & 0.559 & 0.822 \\
\hline $\begin{array}{l}\text { Destination } \\
\text { satisfaction }\end{array}$ & 0.865 & 0.572 & 0.857 \\
\hline Return intention & 0.798 & 0.588 & 0.758 \\
\hline Willingness to pay & 0.839 & 0.636 & 0.813 \\
\hline Word of mouth & 0.859 & 0.691 & 0.826 \\
\hline
\end{tabular}

Table 3. Result of scale reliability (Source: Survey data, 2020)

\begin{tabular}{|l|c|c|c|}
\hline \multicolumn{1}{|c|}{ Scales } & $\begin{array}{c}\text { Number of } \\
\text { variables }\end{array}$ & $\begin{array}{c}\text { Composite } \\
\text { Reliability (Pc) }\end{array}$ & $\begin{array}{c}\text { Variance } \\
\text { Extracted (Pve) }\end{array}$ \\
\hline Push factors & 6 & 0.88 & 0.56 \\
\hline Pull factors & 6 & 0.84 & 0.47 \\
\hline $\begin{array}{l}\text { Destination } \\
\text { satisfaction }\end{array}$ & 5 & 0.86 & 0.55 \\
\hline Return intention & 4 & 0.80 & 0.50 \\
\hline Willingness to pay & 4 & 0.84 & 0.57 \\
\hline Word of mouth & 4 & 0.86 & 0.60 \\
\hline
\end{tabular}

\section{Confirmation Factor Analysis (CFA)}

Based on the CFA analysis results in Table 3, the following coefficients were guaranteed: Chi-square $=467.444(\mathrm{P}=$ 0,000), Chi-square/df $=1.291<2$, with $\mathrm{P}=0.000<0.05$; TLI and CFI are 0.968 and 0.972 , respectively and both are higher than 0.9; RMSEA $=0.035<0.08$ (Bentler and Bonett, 1980). This demonstrates that the model is suitable with the market data. The table above shows that all the standardized regression weights of the scales reach convergent validity. Correlation coefficients between factors are less than 1 with a standard deviation of less than 0.05 .

Therefore, the elements achieve discriminant validity. The result of Composite Reliability (Pc), Variance Extracted (Pvc) presented in Table 3 showed that Pc values are eligible. However, Pvc value of the Push factors scale is slightly low (<0.5), but Pvc could still accept an amount from 0.4 provided that Pc is more significant than 0.6 (Fornell and Larcker, 1981). Thus, all scales are suitable to be used for the SEM analysis step.

\section{Theoretical model and research hypotheses test}

The Structural Equation Modeling (SEM) was used to test the research hypotheses. The result of examining the relationship between factors are shown in Table 4.

Table 4. Testing the relationship between factors (Source: Survey data, 2020)

\begin{tabular}{|c|c|c|c|c|c|c|c|c|}
\hline \multicolumn{2}{|c|}{ Relationship } & \multicolumn{3}{|c|}{ Regression weight } & Standardized & P- & Hypotheses \\
\cline { 3 - 7 } & & Estimated value & Standard Error S.E. & Critical Ratio C.R. \\
regression weight & value & Hy \\
\hline DS & $<---$ & PUS & 0.644 & 0.078 & 8.299 & 0.662 & $* *$ & H1 \\
\hline DS & $<---$ & PUL & 0.656 & 0.079 & 8.267 & 0.764 & $* * *$ & H2 \\
\hline RI & $<---$ & DS & 0.756 & 0.112 & 6.777 & 0.637 & $* * *$ & H3 \\
\hline WTP & $<---$ & DS & 0.886 & 0.113 & 7.837 & 0.825 & $* * *$ & H4 \\
\hline WOM & $<---$ & DS & 0.711 & 0.116 & 6.113 & 0.512 & $* * *$ & H5 \\
\hline
\end{tabular}

Table 4 shows the main findings of the study as follows: 
- Hypothesis H1: Hypothesis H1 was accepted at the significance level of $1 \%$, which is push factors positively impact on the destination satisfaction of tourists towards Can Tho River tourism. This indicates that tourists' intrinsic motivations (learn new things from the river lifestyle, experience the natural beauty and relax in the river area, interact with new friends, explore the culture and history of the river systems) positively affect the satisfaction of tourists. This finding further confirms the importance of push factors in analyzing tourist behaviour. This result is similar to the research of the Fangxuan and Chris (2015), Pratminingsih et al. (2013).

- Hypothesis H2: Hypothesis H2 was accepted at the significance level of $1 \%$, which is pull factors positively affect the destination satisfaction of visitors towards Can Tho River tourism. This result shows that the properties of the destination, as the attraction of nature, the natural beauty of rivers, exciting culture and history, delicious and typical dishes, unique fluvial products, convenient transportation and rest areas, friendly and hospitable local people) positively affect tourist satisfaction. Tourists claim that the natural beauty of rivers is the most important criterion that attracts them, thereby making an essential contribution to tourist satisfaction. This research result is consistent with the finding of Pratminingsih et al. (2013), Mai and Huynh (2014).

- Hypotheses H3, H4, H5: These hypotheses are accepted with a significance level of $1 \%$. This means the destination satisfaction impacts positively on the return intention, willingness to pay, and word of mouth of tourists towards Can Tho River tourism. In other words, if visitors are satisfied with elements of the trip, as fluvial products, cuisine, natural landscape, river environment, culture and history as well as the decision to choose Can Tho as a destination. They will be willing to pay higher service fees, actively have word of mouth about Can Tho River tourism, and tend to return to Can Tho City. This finding is an essential scientific basis for Can Tho's tourism industry in building a strategy to attract tourists and increase tourists' consumption in travel services.

\section{CONCLUSION AND RECOMMENDATIONS}

This research has approached the importance of push and pull factors to destination satisfaction and behavioural intention of tourists towards river tourism in Can Tho City. In particular, pick elements to play an essential role than push factors. This emphasizes the significance of destination attributes in attracting visitors.

Moreover, the study also showed that the increase in tourist satisfaction creates tourists' positive behaviours in the future, including the willingness to pay more, positive word of mouth, and return intention to Can Tho City. From the research results, some implications for the tourism industry of Can Tho City are proposed as follows. Firstly, improve the pull factors that attract visitors to Can Tho River tourism by building an attractive destination image. Promoting the tourism image together with river areas characteristics should be taken into consideration.

Besides, developing programs should focus on creating the impression and attractiveness of river tourism, especially the natural beauty of rivers. Secondly, diversify tourism activities, improve the attractiveness of destinations to meet the needs of visiting, entertaining and experiencing. Tourism activities need to be ensured both practicality and entertainment. These elements help create different feelings and excitement for visitors, therefore bring them unforgettable memories with river tourism in Can Tho City.

\section{REFERENCES}

Bansal, H., \& Eiselt, H.A. (2004). Exploratory research of tourist motivations and planning. Tourism Management, 25(3), 387396. https://doi.org/10.1016/S0261-5177(03)00135-3

Beeho, A.J., \& Prentice R.C. (1997). Conceptualizing the Experiences of Heritage Tourists: A Case Study of New Lanark World Heritage Village. Tourism Management, 18 (2), 75-87. https://doi.org/10.1016/S0261-5177(96)00103-3

Bentler, P.M., \& Bonett, D.G. (1980). Significance tests and goodness of fit in the analysis of covariance structures. Psychological Bulletin, 88(3), 588-606. https://doi.org/10.1037/0033-2909.88.3.588

Carvache-Franco, M., Carvache-Franco, O., Carvache-Franco, W., \& Villagómez-Buele, C. (2020). From Satisfaction in Eco-tourism to Loyalty in a National Park. GeoJournal of Tourism and Geosites, 28 (1), 191-202. https://doi.org/10.30892/gtg.28115-462

Chan, A., Hsu, C.H., \& Baum, T. (2015). The impact of tour service performance on tourist satisfaction and behavioural intentions: A study of Chinese tourists in Hong Kong. Journal of Travel \& Tourism Marketing, 32(1-2), 18-33. https://doi.org/10.1080/10548408.2014.986010

Chen, C.F., \& Chen, F.S. (2009). Experience quality, perceived value, satisfaction and behavioural intentions for heritage tourists. Tourism Management, 31(1), 29-35. https://doi.org/10.1016/j.tourman.2009.02.008

Chen, C.F., \& Tsai, D. (2007). How destination image and evaluative factors affect behavioural intentions?. Tourism Management, 28(4), 1115-1122. https://doi.org/10.1016/j.tourman.2006.07.007

Chon, K.S. (1989). The role of destination image in tourism: A review and discussion. The Tourist Review, 45(2), 2-9. https://doi.org/10.1108/eb058040

Cooper, M., \& Prideaux, B. (2009). Conclusions and challenges. In Prideaux, B. \& Cooper, M. (eds.). River Tourism (pp. 257 - 264). Oxfordshire, UK: CAB International. https://aurora.upsi.edu.my/wp-content/uploads/2021/02/River-Tourism.pdf\#page=267

Crompton, J.L. (1979). Motivations for pleasure vacation. Annals of tourism research, 6(4), 408-424. https://doi.org/10.1016/01607383(79)90004-5

Dann, G.M. (1977). Anomie, ego-enhancement and tourism. Annals of tourism research, 4(4), 184-194. https://doi.org/10.1016/01607383(77)90037-8

Fakeye, P.C., \& Crompton, J.L. (1991). Image differences between prospective, first-time, and repeat visitors to the Lower Rio Grande Valley. Journal of travel research, 30(2), 10-16. https://doi.org/10.1177/004728759103000202

Fangxuan, L., \& Chris, R. (2015). Chinese Tourists' Motivations and Satisfaction of Visiting North Korea. Asia Pacific Journal of Tourism Research, 20(12), 1313-1331. https://doi.org/10.1080/10941665.2014.978343

Fornell, C., \& Larcker, D.F. (1981). Evaluating structural equation models with unobservable variables and measurement error. Journal of Marketing Research, 18(1), 39-50. https://doi.org/10.1177/002224378101800104 
Gnoth, J. (1997). Tourism Motivation and Expectation Formation. Annals of Tourism Research, 24(2), $283-304$. https://doi.org/10.1016/S0160-7383(97)80002-3

Hair, J.F., Anderson, R.E., Tatham, R.L., \& Black, W.C. (1998). Multivariate Data Analysis (5th ed.). New Jersey: Prentice-Hall International.

Hallowell, R. (1996). The relationships of customer satisfaction, customer loyalty, and profitability: an empirical study. International journal of service industry management 7(4), 27-42. https://doi.org/10.1108/09564239610129931

Hasan, A.A., Biswas, C., Roy, M., Akter, S., \& Kuri, B.C. (2020). The Applicability of Theory of Planned Behaviour to Predict Domestic Tourist Behavioural Intention: The Case of Bangladesh. GeoJournal of Tourism and Geosites, 31(3), 1019-1026. https://doi.org/10.30892/gtg.31313-536

Homburg, C., Koschate, N., \& Hoyer, W.D. (2005). Do satisfied customers pay more? A study of the relationship between customer satisfaction and willingness to pay. Journal of Marketing, 69(2), 84-96. https://doi.org/10.1509/jmkg.69.2.84.60760

Hossain, M.S., Mostafa, M.G., \& Hossain, M.A. (2021). Modeling Tourists' Satisfaction In The Nature-Based Tourist Destination Using Structural Equation Modeling Technique. GeoJournal of Tourism and Geosites, 37(3), 814-822. https://doi.org/10.30892/gtg.37311-713

Hoyle, R.H. (1995). The structural equation modelling approach: Basic concepts and fundamental issues. In R. H. Hoyle (Ed.). Structural equation modelling: Concepts, issues, and applications (pp.1-15). Thousand Oaks, CA: Sage Publications. URL: https://psycnet.apa.org/record/1995-97753-001.

Hoelter, D.R. (1983). The analysis of covariance structures: Goodness-of-fit indices. Sociological Methods and Research, 11(3), 325344. https://doi.org/10.1177/0049124183011003003

Hu, Y., \& Ritchie, J.B. (1993). Measuring destination attractiveness: A contextual approach. Journal of travel research, 32(2), 2534. https://doi.org/10.1177/004728759303200204

Ivyanno, U.C. (2013). An Empirical Investigation of Service Quality, Tourist Satisfaction and Future Behavioral Intentions among Domestic Local Tourist at Borobudur Temple. International Journal of Trade, Economics and Finance, 4(2), 86-91. https://doi: 10.7763/ijtef.2013.V4.265

Kim, S.S., Lee, K.C., \& Klenosky, B.D. (2003). The influence of push and pull factors at Korean National Parks. Tourism Management, 24(2), 169-180. https://doi.org/10.1016/S0261-5177(02)00059-6

Kozak, M., \& Rimmington, M. (2000). Tourist satisfaction with Mallorca, Spain, as an offseason holiday destination. Journal of Travel Research, 38(3), 260-269. https://doi.org/10.1177/004728750003800308

Latiff, K., \& Imm, N.S. (2015). The Impact of Tourism Service Quality on Satisfaction. International Journal of Economics and Management, 9(5), 67-94. psasir.upm.edu.my/id/eprint/41750/1/The\%20Impact\%20of\%20Tourism\%20Service\%20Quality\%20on\%20Satisfaction.pdf

Mai, N.K., \& Huynh, T.T.H. (2014). The Influences of Push and Pull Factors on the International Leisure Tourists' Return Intention to Ho Chi Minh City, Vietnam - A Mediation Analysis of Destination Satisfaction. International Journal of Trade, Economics and Finance, 5(6), 490-496. Doi: 10.7763/IJTEF.2014.V5.421

Nunnally, J. (1978). Psychometric Theory. New York: McGraw- Hill.

Peter, J.P., \& Olson, J.C. (1987). Consumer Behavior: Marketing Strategy Perspective. Homewood, Illinois: Richard D. Irwin. 700 Pages.

Peterson, R. (1994). A Meta-Analysis of Cronbach's Coefficient Alpha. Journal of Consumer Research, 21 (2), $381-439$. https://doi.org/10.1086/209405

Pizam, A. (1994). Monitoring Customer Satisfaction. In David, Bernard, Lockwood, Andrew \& Stone, Sally (Eds.). Food and Beverage Management: A Selection of Readings (pp. 231-247). Oxford, UK: Butterworth- Heinemann.

Pratminingsih, A.S., Lipuringtyas, C., \& Rimenta, T. (2013). Factors Influencing Customer Loyalty Toward Online Shopping. International Journal of Trade, Economics and Finance, 4(3), 104-110. Doi.org/10.7763/IJTEF.2013.V4.268

Qiao, G., Chen, N., Guan, Y., \& Kim, S. (2008). Study on Chinese tourists' motivation and satisfaction to visit South Korea. International Journal of Tourism Sciences, 8(1), 17-38. https://doi.org/10.1080/15980634.2008.11434602

Raykov, T., \& Widaman, K.F. (1995). Issues in Applied Structural Equation Modeling Research. Structural Equation Modeling, 2(4), 289-318. https://doi.org/10.1080/10705519509540017

Reisinger, Y., \& Turner, L. (2012). Cross-Cultural Behaviour in Tourism: Concepts and Analysis. Routledge Pulication, pp. 335.

Richard, L.O. (2014). Satisfaction: a behavioural perspective on the consumer. Second Edition. Routledge Pulication, pp. 519.

Ross, E.L., \& Iso-Ahola, S.E. (1991). Sightseeing tourists' motivation and satisfaction. Annals of Tourism Research, 18(2), $226-237$. https://doi.org/10.1016/0160-7383(91)90006-W

Rust, R.T., Zahorik, A.J., \& Keiningham, T.L. (1995). Return of Quality: Measuring the Impact of Your Company's Quest for Quality. Chicago, IL: Irwin Professional Publishing.

Ryan, R.M., \& Deci, E.L. (2000). Intrinsic and extrinsic motivations: Classic definitions and new directions. Contemporary educational psychology, 25(1), 54-67. https://doi.org/10.1006/ceps.1999.1020

Severt, D., Wang, Y., Chen, P., \& Breiter, D. (2007). Examining the motivation, perceived performance, and behavioural intentions of convention attendees: Evidence from a regional conference. Tourism Management, 28(2), 399-408. https://doi.org/10.1016/j.tourman.2006.04.003

Yoon, Y., \& Uysal, M. (2005). An examination of the effects of motivation and satisfaction on destination loyalty: a structural model. Tourism Management, 26(1), 45-56. https://doi.org/10.1016/j.tourman.2003.08.016

Zeithaml, V.A., Berry, L.L., \& Parasuraman, A. (1993). The Nature and Determinants of Customer Expectations of Service. Journal of the Academy of Marketing Science, 21(1), 1-12. https://doi.org/10.1177/0092070393211001

Zeithaml, V., Berry, L., \& Parasuraman, A. (1996). The behavioural consequences of service quality. Journal of Marketing, 60(2), 3146. https://doi.org/10.1177/002224299606000203

Zupan, S., \& Milfelner, B. (2014). Social responsibility, motivation and satisfaction: small hotels guests' perspective. Kybernetes, 43 (3/4), 513-528. https://doi.org/10.1108/K-08-2013-0183

Article history: Received: 15.06.2021 Revised: 10.08.2021 Accepted: 15.09.2021 Available online: 06.10.2021 